\title{
Life project and work as matter of exclusion/inclusion of the elderly person
}

\author{
Projeto de vida e trabalho como questão \\ de exclusão/inclusão da pessoa idosa
}

\author{
Maria de Fátima Fernandes Martins CATÃO' \\ Alice Fernanda Martins GRISI ${ }^{2}$
}

\begin{abstract}
This study was developed based on the reality of population aging, the Aging Era, and the matter of exclusion and psychosocial suffering experienced by elderly people, with the aim of analyzing the meanings of the construction of the life project, work and exclusion/inclusion of this population. A semi-structured interview was performed with 25 participants of the Care for the Elderly Person Program. The lexical and contextual Thematic Content Analysis was performed using the Alcest program for the quantitative analysis of textual data. Three themes were recovered: The world and I: process of exclusion/inclusion - represented $27.77 \%$ of the statements; The Future as the present foremost expressed with 44.44\%; Work and the Life Project as a way of social inclusion - $27.77 \%$. The need for conscious actions was highlighted, with reference to the ethics of citizens who are involved and interested in experiencing aging in a healthier way, in order to humanize the living/aging relationship.
\end{abstract}

Keywords: Aged; Demographic aging; Social exclusion; Social inclusion; Work.

\section{Resumo}

Tendo em vista a realidade do envelhecimento populacional, a Era do Envelhecimento e a questão da exclusão e do padecimento psicossocial vivenciados pela pessoa idosa, desenvolveu-se este estudo, que tem por objetivo analisar os significados da construção do projeto de vida, do trabalho e da exclusão/inclusão por essa população. Foi realizada entrevista semiestruturada com 25 participantes inseridos no Programa de Atenção à Pessoa Idosa, da Secretaria de Desenvolvimento Social da cidade de João Pessoa, Paraíba. Utilizou-se a Análise de Conteúdo Temático de base lexical e contextual com apoio do sistema Alceste de análise de dados textuais. Foram capturados três eixos temáticos: Eu e o mundo: processo de exclusão/inclusão - presente em 27,77\% das falas; O futuro como o presente - eixo mais expresso - presente em $44,44 \%$ das falas; Trabalho e projeto de vida como forma de inclusão social - com $27,77 \%$. Evidencia-se a necessidade de ações conscientes da ética dos cidadãos implicados e interessados em viver envelhecendo de modo mais saudável, humanizando-se, assim, a relação viver/envelhecer.

Palavras-chave: Idoso; Envelhecimento da população; Exclusão social; Inclusão social; Trabalho.

$\nabla \nabla \nabla$

1 Universidade Federal da Paraíba, Centro de Ciências Humanas Letras e Artes, Núcleo de Estudos Psicossociais da Exclusão/ Inclusão e Direitos Humanos. Cidade Universitária, Conjunto Humanístico, Bloco IV, 58059-900, João Pessoa, PB, Brasil. Correspondência para/Correspondence to: M.F.F.M. CATÃO. E-mail: <fathimacatao@uol.com.br>.

2 Psicóloga. João Pessoa, PB, Brasil. 
This study considers the life project and work a matter of exclusion/inclusion for elderly people, and is linked to Núcleo de Estudos Psicossociais da Exclusão/Inclusão e Direitos Humanos (NEIDH, Center for Psychosocial Studies of Exclusion/ Inclusion and Human Rights), being a subproject of the research entitled - Exclusion/Inclusion and the construction of the life project for individuals in the process of exclusion.

The United Nations, stipulates that, over 50 years, from 1975 to 2025, the world's population will enter into an aging process, a phenomenon called the Era of Aging. Currently, Brazil has about 10 million people aged 60 or over, according to data from the World Health Organization (WHO, 2005), which characterizes the country as being in an accelerated aging process - reaching approximately 32 million elderly people in 2025 (Instituto Brasileiro de Geografia e Estatística, 2002).

The national health policy for the elderly person (Brasil, 2006) and the Constitution of the Elderly Person (Brasil, 2003) are legal devices that guide social and healthcare actions, ensure the rights of elderly people, and provide guidance regarding those who require state action to protect them. However, it is known that the effectiveness of a public policy requires a conscious and ethical attitude of the citizens involved and interested in aging in the healthiest way possible. The state, health professionals, elderly people and society in general are all co-responsible for this process. Given the reality of the aging population, the issue of exclusion and psychosocial suffering experienced by elderly people is placed as a priority in the national and international scenario, with investments in care programs for this population supported by research that contributes with indicators of planned insertion/social impact actions. Therefore, the aim of this project was to analyze the meanings of the construction of the life project, work, and exclusion/inclusion for elderly people.

This study was carried out as part of the Programa de Atenção a Pessoa Idosa (PAPI, Care for the Elderly Person Program) in the city of João Pessoa (PB), which is under Federal direction and 216 has its source of funding from taxpayers' money.
The federal government transfers funds and provides technical support to the States, the Federal District, municipalities, and social organizations, which provide care to elderly people through centers and social groups, nursing homes, and clinics, among others. In João Pessoa (PB) PAPI is the responsibility of the Secretariat of Social Development (Headquarters) of the City Hall and is coordinated by the Secretaria Nacional de Assistência Social (SNAS, National Social Assistance Secretariat).

The Programa de Atenção a Pessoa Idosa presents as perspectives the respect and recovery of memory of citizenship and social wellbeing of the elderly, as a subject of rights, regardless of their racial status, gender, spiritual, financial, social or cultural situation, seeking to improve their life quality. Caring for the elderly community, aged over 60 years, which is in a situation of social risk or interested in participating in groups distributed in neighborhoods of the capital city.

The Department of Social Development of the Municipality of João Pessoa (PB), through PAPI, currently serves 1,200 senior citizens in 30 groups, distributed throughout 23 neighborhoods of Paraiba's capital. Anyone over the age of 60 , regardless of socioeconomic status or gender, may participate in the program receiving psychological and social care, with the opportunity to ask questions and receive education regarding their rights.

\section{The elderly person and the construction of the life and work project: A psycho-socio-historical setting}

The human being is psycho-socio-historically configured as an active, social, historical, conscious, transformative, ethical, and responsible person, who has projects, is created and a creator, an individual who is the protagonist of his/her story and simultaneously of social history (Catão, 2001; 2007; 2011; Catão \& Lucena, 2013). Human beings are created in the history that they construct through affections, and from this construction the human psyche, their meanings and their conscience are configured, to the extent that people act on the 
environment and promote changes, both in this environment, and in themselves, through their behavior (Luria, 1990; Vygotsky, 1999; 2001; 2004).

There are several meanings for work, such as the life project setting: as an enjoyable activity of configuration of itself and the everyday experience, the individual is fulfilled as a subject and a social being; is humanized, motivated, and strives. The work makes the human being idealize and want the result of his/her activity to be manifested as concrete knowledge and social cooperation, as people are seen as interacting with the environment and with each other. The production and reproduction of human life, with work as a mediator between man and nature, is essential for the constitution of the subject in his/ her condition of the fulfillment of being and becoming (Marx, 1984), the starting point of the humanization process.

Fernandez (1989) and Antunes (1995), inspired by Marx (1984), cited above, indicate that, with the implementation of the capitalist model of production and the configuration of a utilitarian and mechanistic culture, throughout the twentieth century the meaning of work has no longer been the objectification of the subject as a way to establish him/herself as a human being, who plans activities and then performs them as if possessing their production, but has come to be a way of meeting needs through consumption. Work lost its intrinsic satisfaction, to the same extent that the employee does not recognize himself in what he does, leading to an estrangement felt in postmodern societies (Antunes, 1995; 2004; 2009).

Kim and Moen (2001) conducted a survey with 534 married men and women who were in three distinct phases of retirement: having been so for a long period, recently retired, and about to retire. The results indicated that those who declared themselves as more satisfied with their lives were those who were working part-time because they wanted to. This reality reflects a phenomenon that is common in the United States: that many retirees continue working in new careers or are hired as consultants by their former employers.

\section{Exclusion/Inclusion}

According to Sawaia (2006), when speaking in the dialectic of inclusion/exclusion the idea of humanity and consequently the subject and his/her relationship with the social is thought of as the focal point, set in the center of our thinking, whether in the context of family, work, leisure, or society as a whole. "When speaking of exclusion, one speaks of desire, temporality and affectivity, while also speaking about power, economy, and human and social rights" (p.98). This author also reflected that when perceiving exclusion as human suffering in various ways, one again takes the subject lost in the economic and political relationships in which he/she is inserted, without losing the collective. "It is in the subject that the various forms of exclusion are objectified, being experienced as motivation, needfulness, emotion and the need of the self" (Sawaia, 2006, p.98). To realize the exclusion of these emotions that are objectified in the individual is to reflect on the (dis)engagement with human suffering, suffering that does not have its origins in itself, but rather in the relationships with one another and with the world.

Studies made by Flament (1996) on social exclusion and work show that social inclusion through work is very present in the speech of individuals within the 50 to 60 years age group. This is the way of social inclusion more present in contemporary societies, where work, as a mediator between the individual and society, offers the subject dignity and identity. Accordingly, Sawaia (2006) highlights that to speak of social exclusion/ inclusion is to go beyond the right to material survival: people die of hunger, but also die of sadness, due to lack or absence of dignity.

According to studies conducted in Brazil, the aging condition is still unappreciated, the elaboration of the meanings of aging as being a loss, are still salient aspects (Debert, 2000). It is currently noticeable, even if only slightly, that the conceptual changes of meanings associated with aging and retirement itself are slowly gaining a sense of freedom, of charting new goals, and attaining 
new achievements and personal satisfaction. The experiences accumulated over a lifetime now represent the possibility for constructing new identities, resuming old projects, and beginning new constructions of relationships with the world and those around them (Derbert, 2000; Felix \& Catão, 2013; Flament, 1996; França \& Stepansky, 2005; Neri, 2008;).

In this sense, current trends are indicated, from demands and studies about aging, based on knowledge of the possibilities of a healthy lifestyle for elderly people: attempts to deconstruct the meanings and historical meanings of being elderly - such as illness, end of work and activity, loss of social ties (Derbert, 2000; França \& Stepansky, 2005; Flament, 1996; Neri, 2008), with the creation of a new culture where the focus is on the constitution of the subject. (Gonzalez, 2004; Vygotsky, 2004)

\section{Method}

This study was carried out in the Care for the Elderly Person Program Center/Social Development Secretariat (Headquarters) Municipality of the city of João Pessoa (PB), coordinated by the National Department of Social Assistance.

\section{Participants}

The Department of Social Development of the Municipality of João Pessoa (PB) through the Care for the Elderly Person Program, currently serves 1,200 senior citizens in 30 groups, distributed throughout 23 districts of the capital of Paraiba. For the researcher's convenience a PAPI social group was chosen located close to the University generating this research. Approximately 40 elderly women participate in this group and 25 participated in the study, due to being present at the weekly meetings of which the researcher participated. In the participant group (25 elderly women), 88\% were in the age group between 70 and 85 years. Regarding education, $84 \%$ had completed the $1^{\text {st }}$ or $2^{\text {nd }}$ year of high school and $16 \%$ had completed 218 the high school education. Of these women, 32\% were married, $16 \%$ single and $52 \%$ widows. Regarding the family income, $4 \%$ had an income of one minimum wage, $64 \%$ had an income between two and four minimum wages, 24\% between five and nine minimum wages, and $8 \%$ had a family income greater than ten minimum wages. A total of $4 \%$ lived alone, $48 \%$ with one or two people, $44 \%$, with three to five people, and $4 \%$, lived with more than five people.

\section{Data collection procedure and Instruments for}

Upon acceptance from the coordinating group of PAPI and the members of the group (the elderly people), the field activities were started, following all ethical research procedures related to the performance of the study. Two questionnaires were used: one with the aim of mapping the psychosocial profile of the PAPI and the other aiming to identify the socio-demographic variables of the group's members, with a semi-structured interview that addressed aspects of the construction of the Life Project, work and exclusion/inclusion, with the following introductory questions: When I say Life Project, what comes to mind? When I say work, what comes to mind? How do you see the world? How do you see yourself? How do you see yourself in the world today?

\section{Data analysis procedures}

Content Analysis Methodology was used in the interpretation and analysis of the meanings that emerged from the statements of the participants. To this end, lexical and contextual analysis was performed, based on the Alceste-automatic system of textual data analysis, designed by Reinert (1990; 1993) Units that make up the text are called Elementary Context Units (ECU) which originate from the contextual meanings of sentences and paragraphs. In this study, a total of 72 ECU were configured.

The analysis plan applied was developed as follows: organization of the corpus, consisting of 
the 25 interviews with the elderly people; preparation of the files for the Alceste system, data processing by Alceste, and in-depth reading and referential interpretation. This procedure constitutes the identification of themes, contextual fields and their lexical meanings and reflection, denominating the senses to the theoretical and conceptual framework of the study. Therefore, attention was given to the manifest content in order to deepen the analysis and uncover the latent content expressed in the statements of the study participants. Based on resolution n $n^{\circ} 196 / 96$ of the CNS/MS, this study was approved by the Research Ethics Committee of the Lauro Wanderley Hospital of the Universidade Federal da Paraíba, Protocol $n^{\circ} 068 / 09$.

\section{Results and Discussion}

This study aimed to emphasize not only the construction of the meaning of the life project, but also to provide the participants with a moment of reflection regarding this construction. This reflection was visualized to the extent that the construction of the meaning is intertwined with the world experienced by these individuals, so that the life project is no longer configured as something external, but rather as part of their history. The meanings of the life project and work as means of exclusion/inclusion for elderly people, based on the material collected from the interviews, were perceived as three themes: The world and I: Exclusion/Inclusion process, present in $27.77 \%$ of the statements; the Future as the present, as the thematic axis more expressed by the elderly people, with 32 ECU totaling $44.44 \%$ of the statements, and Work and the Life Project as means of social inclusion with $27.77 \%$ - as shown in the Table 1.

\section{The world and I: The process of exclusion/inclusion}

The work and Life Project as a vision of themselves and the world for the elderly people also involves the social exclusion/inclusion dialectic. The view of themselves is characterized as an
Table 1

Distribution of elementary context units of the meanings of life project and work as means of exclusion/inclusion of the elderly person

\begin{tabular}{lcc}
\hline \multirow{2}{*}{ Thematic groups } & \multicolumn{2}{c}{ ECU } \\
\cline { 2 - 4 } & ECU & $\%$ \\
\hline The world and I: The process of exclusion/inclusion & 20 & 27.77 \\
The future as the present & 32 & 44.44 \\
Work and life project as means of social inclusion & 20 & 27.77 \\
\hline Total & 72 & 100.00 \\
\hline
\end{tabular}

Note: ECU: Elementary Context Units.

essential point with regard to the individual conscience of their own history and its construction process, becoming closely linked to the World Vision, to the extent that these two constructions are intertwined, i.e., the human being as a complex, being product and producer of the environment where he/she lives, as can be seen in the following statements:

I see myself as a creature that struggled and is happy despite being poor and illiterate. I feel like I am someone. I am very well-liked by people (72 years of age). I see myself as an old person at the end of life (83 years of age). I find myself afraid of violence (83 years of age). The world is sad, you see! It is very violent! (83 years of age).

The vision of herself: I see myself as an old person at the end of life ( 83 years of age), reveals a sense of the power of suffering in relation to the continuity of life, a human being who, for various reasons, just waits for the days to go by. Retirement reveals this condition here, as if these people had nothing else to do in this world. The way they see themselves is very limited due to tiredness, old age, passivity, and feelings of worthlessness and exclusion. The exclusion process disintegrates the identity of the individuals and excluded groups; disarranges social relationships, is an affront to human dignity, reflects a feeling of abandonment, and promotes marginalization and delinquency. Exclusion and inclusion are changeable, reversible between each other, mixing each other, replacing one another and shaping themselves. The relationship between the individual and society engenders the process of inclusion/exclusion and 
causes the need for reflection on what people are presumed to be and their social and psychological well-being. "It is in the subject that the various forms of exclusion are objectified, being experienced as motivation, needfulness, emotion and the need of the self" (Sawaia, 2006, p.98). To recognize exclusion through these emotions that are objectified in the individuals is to reflect on the (dis)engagement with human suffering and that suffering does not have its origins in itself, but rather in the relationships with others and with the world.

Feelings of sadness at the progress that people attribute to the world and to society can be found in the statements: I find myself afraid of violence. (83 years of age). The world is sad, you see! It is very violent! (83 years of age). The issue of exclusion/inclusion, at the moment that this person perceives the world's violence, social injustice, while feeling unable to change this framework, causes him/her to retreat into the fear of exclusion and violence. In the majority of the statements, there was a passive attitude, that of a person who could be active and could be making changes in the environment he/she lives in, but that in some way is obstructed, is reduced to the condition of being an elderly person. Is this the position that today's senior citizens should have? Is this the posture that future senior citizens want to have with time? When stopping to reflect, one thinks: Do we want to continue to be woven into a social fabric that excludes and scares us? And what can be done to change this situation? Culture is an essential part of the formation of people and their life projects. It is thought to be necessary to reflect on the culture of social inequality, disrespect for differences, and affront to the human dignity, and that passive citizenship is limited to the formal aspects of democratic rituals, the culture of injustice and lack of solidarity that has led to exclusion and a reduction in the space of equality between social groups and the exclusion (Catão, 2007a).

In the participating group $100 \%$ of the people were women, of which $88 \%$ were in the 70 to 85 years age group. Regarding education, $84 \%$ completed the $1^{\text {st }}$ or $2^{\text {nd }}$ year of high school, and 220 had an income between two and four minimum wages. The participation of only women in this study was due to the composition of the group studied, as it contained no elderly men. Regarding the aspects: low income, being older, and having lived a lonely life, these constitute part of a cultural historical condition that raises the issue of social class - The world and I: Exclusion/Inclusion, with the requirement for reflection and intervention/ transformation.

\section{The future as the present}

The Life Project was presented as a major weakness of the elderly people in question. They failed to see anything in the nearer future and just saw their future as being the same as the way they were living at that moment, i.e., they saw the future as the present, without any other possibilities regarding what was to come,

My future is this, the way I am today ( 74
years of age). The future is as it is today ( 77
years of age). I have no future anymore. I'll
be older than I am today, but I want to have
the same conditions that I have today ( 79
years of age) I expect nothing more ( 84 years
of age).

The power of the suffering of these individuals can be perceived because, given the condition of elderly people, they see themselves at the end of their journey in society and not as active subjects and builders of their own history: I don't have a future anymore. I'll be older than I am today, but I want to have the same conditions I do today (79 years of age). This feeling of lack of perspective for the future was very frequent in the discourses of the retired women: The only thing I expect of the future is death. I do not expect anything else (84 years of age). The retired women could only see themselves at the end of their lives and not on a continuous construction of themselves, i.e., the future arises as the present and this is as if they had nothing more to accomplish in their life, wishing to live out "their last days" well.

The human being is configured psychosocio-historically as an active, social, historical, 
conscious, transformative, ethical, and responsible being, who has projects, is created and a creator, an individual who is the protagonist of his/her own story and simultaneously of social history (Catão, 2007b). To the extent to which people act in the environment, they promote changes, both in their environment, as in themselves, through their behavior (Luria, 1990; Vygotsky, 1999; 2001; 2004).

\section{Work and the life project as means of social inclusion}

The Life Project was also perceived from their relationship with work. Work as a way to include the subject in society, as a way of maintaining human activity.

Work is a very good thing. At least we move ourselves. Those who do not work get sick (66 years of age). Work is a very good thing. Without work we are nobody (77 years of age). Having a life plan is to have conditions to carry out a project (74 years of age). The life project is a good thing for those who are young (77 years of age). My life project is to learn and have friends (74 years of age).

Work as a very good thing, as activity development, as facing reality, and as a realization of human beings included in society was captured in the words of the subjects: Work is a very good thing. Without work we are nobody (77 years of age). The elderly phase does not mean the loss of work, but rather work as an achievement for people, a work done, no longer as an obligation, but rather as the search for oneself. Work means development, social relationships, helping others, a way to move, to feel able to perform an activity, to achieve things not only as a professional but also as a human being: Work is wonderful. The person has to give a little of him/her for himself/herself and others (72 years of age). This moment of the study was satisfying because the importance of work in their lives could be perceived as a source of happiness, of fulfillment, of accomplishment and not as means of material survival anymore. In this way work becomes a source of humanization.
Work is understood as a contradictory political phenomenon of: construction/deconstruction and maintenance/transformation of the individual and society, to be understood, primarily, as an ontological condition of human existence and a mediator of the constitution of the subject and the world, through the activity. (Clot, 2006; 2011; Leontiev, 1978; Vygotsky, 2004; 2010). Conversely, work from a productivist perspective of the service model, has the objective of a means to maintain consumption and the market, distancing the individual from him/herself and his/her humanity. To think about work and the life project, at the elderly stage of life is a current challenge, which, at some time, will become the daily life of most of the world's population. The project is a way of making the individual evolve, learn, face life, it is to make the person happy and involved in a continuous construction of new projects and new achievements: The life project is important because it makes us face life. My life project is to help those in need (66 year of age).

França (1989) stated that the social identity is marked by the bond of relationships established during work throughout the life of the subject. Even those who wish to retire normally want to maintain some sort of activity, whether paid or unpaid, related to their interests and personal projects. While some people actually want to stop working, without having plans regarding what they would like to do, others can imagine projects, with few being able to specify details about these projects, or what they would actually do at the time of retirement. It is believed that this study and its correspondent contributions have limitations and deficiencies that may be identified by other researchers, however, it is also believed that such gaps serve as boundaries and new challenges for new studies and that others are directed towards an increasingly open dialogue, extending the knowledge regarding the subject of this study: the life project and work as means of exclusion/ inclusion of the elderly person.

The final considerations must enter into a time of reflection, embarking on the path of public policies for social inclusion, such as the PAPI - Care Program for the Elderly Person- source of this 
research. But also, one needs to develop a mental inclusion policy. That would be: To cause in ourselves and in others, from children to elderly people, the constitution of meanings and senses that all human beings have a space that is theirs and, regardless of age, all have an active role in the world. We have to start acting in the eye of the social fabric, which are children and adolescents. Promote a process of critical analysis of the lived, in order to be able to set up a new culture on human development, as a continuous process, causing also the possibility of thinking about aging linked to building projects, to work, to inclusion with citizenship humanization of themselves, of each other, the relationships in living with differences, at any age, in any space and time.

The constitution of the person is carried out in a continuous process throughout his/her life, not being possible, at any moment of time, for it to be considered finalized or even completely understood. This gives the person the quality of complexity, not in the sense of being difficult to understand, but in order to be intertwined and inseparable from a historicity that configures and gives meaning to the existence. This complexity causes people to produce themselves in the various higher psychological operations that occur throughout their development. Given the above it is our responsibility as professionals and also as human beings, products and producers of our history and the history of those who interact with us in any way in our lives, of forming human beings increasingly conscious of the constant process of choice in this construction.

\section{References}

Antunes, R. (1995). Trabalho e estranhamento. In R. Antunes. Adeus ao trabalho? Ensaio sobre as metamorfoses e a centralidade do mundo do trabalho. São Paulo: Cortez.

Antunes, R. (2004). A dialética do trabalho: escritos de Marx e Engels. São Paulo: Expressão Popular.

Antunes, R. (2009). Os sentidos do trabalho: ensaios sobre a afirmação e a negação do trabalho. São Paulo: Boitempo.

Brasil. Ministério da Saúde. (2003). Estatuto do idoso. Brasília: Ministério da Saúde.

Brasil. Ministro de Estado da Saúde. (2006). Portaria n 222 2.528 de 19 de outubro de 2006. Aprova a Política
Nacional de Saúde do Idoso Brasília. Diário Oficial da União, Seção 1, p.20.

Catão, M. F. (2001). Projeto de vida em construção: na exclusão/inserção social (Vol. 500). João Pessoa: Editora Universitária.

Catão , M. F. (2007a). O que pedem as pessoas da vida e o que desejam nela realizar? In E. C., Krutzen \& S. Brazão. Psicologia social, clínica e saúde mental (pp.75-94). João Pessoa: Editora Universitária.

Catão, M. F. (2007b). Problemas sociais e análise psicológica: questões de método. In M. F. Catão. Análise psicológica de problemas sociais concretos: proposições analíticas (Relatório de Pesquisa de Pós-Doutorado não-publicada). São Paulo: PUCSP.

Catão, M. F. (2011). O ser humano e problemas sociais: questões de intervenção. Temas em Psicologia, 19(2), 459-465.

Catão, M. F, \& Lucena, M. S. R. (2013). Womem in situations of gender violence: Meanings of affective experience. Psicologia \& Sociedade, 25(Spe.), 122-130

Clot, Y. (2006). A função psicológica do trabalho. Petrópolis: Vozes.

Clot, Y. (2011). Clínica do trabalho e clínica da atividade. In P .F., Bendassoli \& L. A. Soboli (Orgs.), Clínicas do trabalho. São Paulo: Atlas

Debert, G. G. (2000). O significado da velhice na sociedade brasileira. Acta Paulista de Enfermagem, 12(Esp. Pt 1), 147-158.

Felix, Y. T. M., \& Catão, M., F. (2013). Envelhecimento e aposentadoria por policias rodoviários. Psicologia \& Sociedade, 25(2), 420-429.

Fernández, M. E. (1989). A face oculta da escola: educação e trabalho no capitalismo. Porto Alegre: Artes Médicas.

Flamment, C. (1996). Les valeurs du travail, la psychologie des representations socials comme observatoire d'un cangemente historique. In J. C. Abric (Ed.), Exclusion sociale, insertion et prevention. France: Ėres.

França, L. H. (1989). A busca de um sentido existencial para o idoso (Dissertação de mestrado não-publicada). Universidade Federal do Rio de Janeiro.

França, L. H., \& Stepansky, D. V. (2005). Educação permanente para trabalhadores idosos: o retorno à rede social. Boletim Técnico do Senac, 31(2), 47-55.

Gonzalez, R. F. (2004). A emergência do sujeito e a subjetividade: sua implicação para a psicologia social. In F. R. Gonzalez. O social na psicologia e a psicologia social. Petrópolis: Vozes

Instituto Brasileiro de Geografia e Estatística. (2002). Perfil dos idosos responsáveis pelos domicilios no Brasil: estudos e pesquisas. Brasília: Instituto Brasileiro de Geografia e Estatística. 
Kim, J., \& Moen, P. (2001). Is retirement good or bad for subjective well-being? Current Directions in Psychological Science, 10, 83-86.

Leontiev, A. N. (1978). O desenvolvimento do psiquismo. Lisboa: Livros Horizonte.

Luria, A. (1990). Desenvolvimento cognitivo: seus fundamentos culturais e sociais. São Paulo: Íncone.

Marx, K. (1984). O capital. São Paulo: Dicel.

Neri, A. (2008). Velhice e qualidade de vida na mulher. In A. Neri. Desenvolvimento e envelhecimento perspectivas biológicas, psicológicas e sociológicas. Campinas: Papirus.

Reinert, M. (1990). Alceste: une méthodologie d'analyse des données textuelles et une application: Aurelia de Gerard de Nerval. Bulletin de Méthodologie, 26, 24-54.

Reinert, M. (1993). Les mondes lexicaux et leur logique travers l'analyse statisque d"um corpus de récits de cauchemars. Language et Societé, 66, 5-39.

Sawaia, B. B. (2006). O sofrimento ético-político como categoria de análise da dialética da exclusão/inclusão.
In B. B. Sawaia (Org), As artimanhas da exclusão: análise psicossocial e ética da desigualdade social (6 $6^{\text {a }}$ ed.). Petrópolis: Vozes.

World Health Organization. (2005). Envelhecimento ativo: uma política de saúde. Brasília: Organização Pan-Americana da Saúde.

Vygotsky, L. S. (1999). A formação social da mente: o desenvolvimento dos processos psicológicos superiores ( $6^{\mathrm{a}}$ ed.). São Paulo: Martins Fontes.

Vygotsky, L. S. ( 2001). A construção do pensamento e linguagem. São Paulo: Martins Fontes.

Vygotsky, L. S. (2004). Teoria e método em psicologia. São Paulo: Martins Fontes.

Vygotsky, L. S. (2010). Psicologia pedagógica. São Paulo: Martins Fontes.

Received on: 19/6/2012

Final version on: 6/7/2012

Approved on: 26/7/2012 
